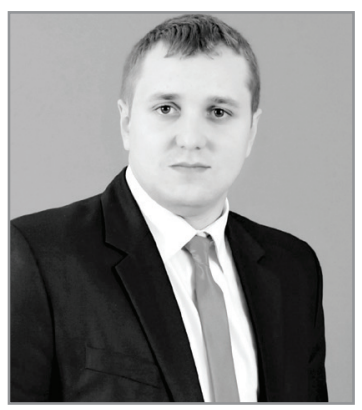

\title{
Serhii Andrushchenko
}

National School of Judges of Ukraine

(120A, Zhylianska St., Kyiv, Ukraine)

https://orcid.org/0000-0003-1209-3286

Andrushchenko, S. (2020). The Regime of Seaports in Ukraine: A Complicated Way to Updating Legal Regulation. Lex Portus, 3, 44-62. https://doi.org/10.26886/2524-101X.3.2020.3

\section{THE REGIME OF SEAPORTS IN UKRAINE: A COMPLICATED WAY TO UPDATING LEGAL REGULATION}

\section{ABSTRACT}

The article outlines the advantages and disadvantages of the current legislation of Ukraine in the field of establishing the legal regime of seaports. The documents of long-term strategic planning in the maritime sphere, international agreements and sectoral (port) legislation are analyzed. It is determined that neither the program documents of the maritime sphere of Ukraine, nor other national legislation of the port sphere contain generalized norms on the regimes of seaports, but outline their components. The first indicates the need and ways to improve them, and the second - these components are regulated in detail and clearly specified, 
comprehensively characterize the established regimes of seaports, but only from the standpoint of domestic law, not taking into account international (bilateral) agreements on merchant shipping. At the same time, these agreements determine one of the largest elements of the integrated regime of seaports - the regime of ships under foreign flags and the regime of their crews. The author proposes to amend the current legislation of Ukraine in the field of port activities and indicate in it the determinism of the regimes of seaports of Ukraine not only of domestic legislation but also of the rules of bilateral agreements on merchant shipping. It is also noted that such norms can be enshrined in the future law of Ukraine on inland waters, the territorial sea and the continental shelf.

The key words: port, seaport, seaport regime, development of port legislation, public administration of port activities.

\section{Introduction}

Ensuring the freedom of access to the seaports of vessels flying foreign flags and optimizing port formalities determine the dynamic development not only of coastal areas, but also of countries as a whole. The choice of modes in seaports usually determines the choice of their hubs, which ultimately contributes to the development of intercontinental relations and global mobility of goods and people. Today, maritime transport chains are significantly affected by digital technologies, remaining the leading means of transporting goods. Port states try to attract trade flows by competing for loyalty to the established legal regimes and providing the most favourable conditions for the processing of goods and other services. The increase of cargo volume enhanced ports as major accelerators of national economic development, increasing the interest in port commercialisation, as governments look for ways to enhance their port efficiency, productivity, competitiveness, and financially viability (Dimitriou, Mourmouris, Sartzetaki, 2017, p. 210). For Ukraine in the situation in the Black Sea region, along with the situational changes in the legislation, it is relevant the issue of comprehensive renewal of the legal provision of the port sector, based on the best practices of the world's leading ports, taking into account national characteristics and providing broad financial support. 


\section{Methodology}

Based on the analysis of the current legislation, the shortcomings of the legal regulation of the regime of seaports of Ukraine were identified and characterized. Program documents of long-term strategic planning of the maritime industry, international agreements and acts of sectoral legislation, which define the regime rules of seaports of Ukraine, are considered. In order to form elements of the scientific concept of reforming Ukrainian legislation using the method of scientific forecasting, recommendations have been developed to update and improve Ukrainian legislation in the field of port activities, in particular on legal support of legal regimes in Ukrainian ports. The set of methods chosen for the study was supplemented by formal-legal and comparative one, which provided an opportunity to study the texts of Ukrainian legislation in the field of maritime activities in the projection of the study to outline their positive and negative features, compare their techniques and identify ways to overcome some shortcomings.

\section{Program documents of Ukraine in the field of maritime transport and issues of legal regimes of ports}

The long-term strategic planning documents in the most important spheres of socio-political life began to be actively developed and adopted in Ukraine in the mid and late 2000s. It was during this period that the leading vectors of the development in the maritime, military, information and tax spheres were identified and reformed. And although the relevant doctrines and strategies currently have several editions or have expired, they have retained their importance in identifying areas for renewal and improving the functioning of relevant areas. The norms of these documents can be assessed differently, their effectiveness and significance for the restoration and improvement of relevant legislation and law enforcement practice can be argued, but their importance as a kind of "road map" is difficult to overestimate. They have led to extensive work on updating existing 
legislation, significant institutional changes in relevant areas, etc. But, unfortunately, we should admit the existing and in some cases critical slowness of their updating, as well as weak correlation of norms which provides grounds for their further analysis and offering opportunities to overcome some shortcomings (Kivalov, 2018, p. 13-14).

Continuing the reflections on the Maritime Doctrine of Ukraine for the period up to 2035, which has undergone significant updates at the end of 2018, the following should be noted. This document, disclosing the directions of reforming port activities, does not contain the norms that define or contain references to the legal regime of seaports of Ukraine or general norms that could become the basis for the formation of sectoral legislation. At the same time, the Doctrine repeatedly mentions the elements of such a legal regime. Thus, the attention is paid to the need to comply with international standards of maritime safety and security of ships and ports, the importance of a well-structured system of maritime safety and security of ships and port facilities, and development, efficiency and competitiveness of seaports are recognized as one of Ukraine's national interests at sea. In addition, in the Doctrine it is stated that for the general improvement of maritime activities it is necessary to: improve the system of taxation and customs regulation, as well as balance the state tariff policy on maritime transport, the collection of port dues; solve the problems of seaport development, first of all increase the efficiency of economic investment, reduce the restrictions on the implementation of regional transport projects, increase the level of implementation of international standards in the activities of government agencies in seaports, create modern regulatory and technical support for port and waterway design. These components, in combination with the rules established by the coastal state for visiting ports, carrying out various activities in them, etc., in our opinion, form a rather complex, formed of many different regimes, the so-called "Conglomerate of regime rules" (Averochkina, 2018, p. 131), which is characteristic of each of the seaports of Ukraine. 
Other policy documents of the industry - the Strategy for the Development of Seaports of Ukraine until 2038 and the National Transport Strategy of Ukraine for the period until 2030 - identify areas for improvement of port activities, including port regimes, similar to the Doctrine and do not contain any definitions or characteristics of such regimes, focusing on identifying areas for reforming their elements. For example, the National Transport Strategy of Ukraine for the period up to 2030 states the need to increase the efficiency and concession of state stevedoring companies in seaports, development and approval of methods for calculating port dues, revision of their size taking into account the structure and directions of cargo flows, entry of Ukrainian seaports in the top 100 largest ports in the world in terms of container handling, etc. And the Strategy for the Development of Seaports of Ukraine for the period up to 2038 is generally devoted to the definition of the main ideas of almost complete reform of the entire seaport industry.

It should be noted that the analysis of the texts of these documents shows a high level of duplication of norms, stopping attention on the same problematic aspects of the functioning of the port industry of Ukraine. At the same time, none of them contains a specific plan for the implementation of planned activities, does not determine the responsible executors and does not set the deadlines. Of course, such work plans may not be part of the program documents, but they can be developed and adopted for their "development". And their absence, in our opinion, reduces the effectiveness of strategic planning and nullifies the implementation of the declared provisions. In addition, given that in fact the norms of the Doctrine and Strategies determine the directions of reforming the regimes of seaports of Ukraine, they should mention the regimes in force in the seaports of Ukraine, as well as place a general reference to their determination by the international agreements and sectoral legislation. 


\section{Legal regime of the port in international agreements and sectoral (port) legislation of Ukraine}

Existing and supported by most countries of the world the international maritime agreements do not contain generalized comprehensive rules for the establishment and maintenance of seaport regimes. This is due to the fact that port territories (water and land) belong to the state territories and with regard to the conditions of activity in them, countries do not express a strong desire to limit their own sovereignty and jurisdiction. However, this does not mean that the regime rules do not fall under the rules of international agreements. After all, it is important to optimize foreign economic relations to decide the issue of eliminating, minimizing differences in legal norms of different states, which can be done through the unification of legal norms, which is based on the conclusion of multilateral and bilateral agreements of universal or regional nature for the purpose of uniform application of legal norms in separate spheres of legal relations (Brazovskaya, Zhelonkin, 2019, p. 1639). Because the impact of shipping and seaport sector on the socioeconomic activity is undeniable. The history of human development and civilisation growth is directly connected with the access to the seas (Zaucha, Matczak, 2018).

The first international documents adopted by the League of Nations to define the seaport regime were the Convention and Statute on the International Regime of Maritime Ports 1923. In particular, the Statute provides that

«Subject to the principle of reciprocity and to the reservation set out in the first paragraph of Article 8, every contracting state undertakes to grant the vessels of every other contracting state equality of treatment wirh its own vessels, or those of any other state whatsoever, in the maritime ports situated under its sovereignty or authority, as regards freedom of access to the port, the use of the port, and the full enjoyment of the benefits as regards navigation and commercial operations which it affords to vessels, their cargoes and passengers". 
However, due to the fact that the accession to the Convention and the Statute did not become global, the states introduced the practice of concluding bilateral agreements on trade and shipping (Kuznetsov, Averochkina, 2011, p. 89). It was in these agreements that the principle of reciprocity established by the Statute of 1923 and the national regime granted to ships under the flags of the contracting parties were embodied. Subsequently, the most-favoured-nation and most-favoured-nation treatment was added to the national regime, as well as other regimes that largely combined the requirements of existing ones and provided new features to the process of liberalizing attitudes towards ships in ports.

In addition, despite the fact that the establishment of the regime of seaports is a "matter" within the state, the rules of international agreements, which have become valid in the prescribed manner for the port state, they still apply. Moreover, they determine the directions of changes in domestic legislation, its further development, as well as relevant law enforcement practices. One such agreement is the 1965 Convention on the Facilitation of International Maritime Traffic, which defined mechanisms for simplifying and reducing to a minimum the formalities, documentary requirements and procedures on the arrival, stay and departure of ships engaged in international voyages.

In accordance with the provisions of this Convention,

\section{"Article II}

(1) The Contracting Governments undertake to co-operate, in accordance with the provisions of the present Convention, in the formulation and application of measures for the facilitation of the arrival, stay and departure of ships. Such measures shall be, to the fullest extent practicable, not less favourable than measures applied in respect of other means of international transport; however, these measures may differ according to particular requirements.

(2) The measures for the facilitation of international maritime traffic provided for under the present Convention and its Annex apply equally to the ships of coastal and non-coastal States the Governments of which are Parties to the present Convention. 
(3) The provisions of the present Convention do not apply to warships or pleasure yachts.

\section{Article III}

The Contracting Governments undertake to co-operate in securing the highest practicable degree of uniformity in formalities, documentary requirements and procedures in all matters in which such uniformity will facilitate and improve international maritime traffic and keep to a minimum any alterations in formalities, documentary requirements and procedures necessary to meet special requirements of a domestic nature".

It is the standards of this Convention set out in the Annex to this Convention that have become the guiding principle for the updating of domestic legislation. However, although Ukraine joined FAL 65 in 1993, the relevant changes in the legislation began to take place actively only in 2006, when the Procedure for registration of arrival from departure and departure of vessels of the fishing industry by captains of the sea fishing ports of Ukraine was approved, and only in 2013 it was adopted the Procedure for registration of arrival of vessels in the seaport, granting permission for exit of vessels to the sea and registration of exit of vessels from the seaport. These documents comply with the FAL 65 standards and have significantly updated the existing legal regulation of the set of formalities required for entry and exit from Ukrainian seaports.

In 2012, the Law "On Seaports of Ukraine" was adopted, which repeatedly mentions the regimes in force in the seaports of Ukraine. Thus, the Law contains the norms on the legal regime of port infrastructure facilities (Article 2), on the regime of stay in the seaport (Article 10), on the regime at the checkpoint across the state border of Ukraine and customs control in the seaport (Article 11), the sanitary, quarantine, fire regimes (Article 17), the legal regime of property in the seaport (Article 23), the legal regime of seaport lands (Article 24). Really, the way in which ports have evolved in recent times has been determined by the changeability of port functions, brought about by such factors as break-throughs in vessel technology, developments affecting the equipment used to load and unload 
cargos or the new storage techniques that have been implemented, transformations affecting international trade patterns, modifications to the way that maritime transport is organized, the development of sophisticated information and communication systems and the need for more complex global logistics chains (De Sousa, Fernandes, 2009, p. 87).

As rightly noted in modern research periodicals, in Art. 10 "Regime of stay in the seaport" of the Law on Seaports, the term "regime" covers the established rules of stay and movement within the seaport, i.e. the rules relating to admission to the territory and waters of the port, the implementation of certain actions (entry, stay, departure, cargo and transshipment operations, cargo storage, staff work, etc.), maintaining the order. It also includes the understanding of this term as a set of rules applicable to ships in accordance with concluded agreements on merchant shipping (national regime, most-favoured-nation treatment) and ensuring compliance with the seawater regime as part of inland waters (Serafimov, 2017, p. 102). Although the latter thesis (concerning the national regime and the most-favoured-nation regime), in our opinion, is quite broad and has no clear confirmation in the Law.

By its legal nature, this regime is administrative law, established by the rules of administrative law aimed at regulating relations of an imperative nature and, according to the definitions developed in administrative law, is a specific procedure for legal entities in various spheres of public life, in particular, in the port transport sector. It is established in laws and bylaws and is aimed at their strictly targeted and functional activities in those areas where additional means are needed to maintain the necessary statehood (Tihomirov, 2001, p. 325). And here once again it is confirmed the thesis that administrative and legal regimes are not only a tool for regulating certain negative aspects of socio-political life (emergencies, martial law, etc.), but also have a focus on its so-called positive regulation, which, in our opinion, is much broader 
and is designed for daily continuous application and promotion of "the effectiveness of the functioning of state structures in their impact on social processes" (Mailjan, 2002, p. 8). And also that the practical implementation of state jurisdiction over the marine environment goes into the sphere of national administrative law (Kormych, Averochkina, Gaverskyi, 2020).

The next type of normative documents, which determine the regime rules of seaports of Ukraine, are Compulsory regulations and Codes of customs. These documents are adopted in order to determine and regulate the legal regime of each of the seaports of Ukraine, they specify the provisions of the Law on Seaports and other legislation, contain a set of technical regulations for the operation of ports. In essence, they are local, because they apply only to a specific, clearly defined, seaport, play a supporting but significant role to ensure that each port is able to effectively implement the functions provided. According to researchers, local legal acts are adopted to clarify and specify the rules of law, establish mechanisms for their implementation, introduce other models of regulation of local relations compared to those provided by law, as far as the law allows, or they fix the choice of one of the alternative models to fill the gaps of legislation, due to special provisions of the legislation (Tychkova, 2009 , p. 9). And although these acts have some differences from local acts adopted by the governing bodies of legal entities, and are considered as such in accordance with the classical views of researchers of rule-making in various fields of law, they can still be referred, due to the extension of clearly defined territory and waters, precisely to the group of acts of local legal regulation.

According to Art. 9 of the Law on Seaports, the Code of Customs establishes the rules for the provision of services in the seaport, the service of ships and passengers, which have developed and have long been applied in practice in this seaport. It contains rules on: 1) the procedure for delivery of the notice of readiness of the vessel for cargo operations; 2) the procedure for calculating the fixed time, 
if it is not established by agreement of the parties; 3) a list of services provided at the seaport; 4) other rules for conducting business operations within the seaport. The code of customs of the seaport is applied: 1) in the presence in the contract of sea transportation of conditions concerning application of customs of the sea port; 2) in the absence in the contract of sea transportation of the relevant rules on matters governed by the customs of the seaport; 3 ) in the presence in the contract of sea transportation of the conditions contradicting customs of the seaport. The Code of Seaport Customs is issued by the Ukrainian Sea Ports Authority for each seaport, certified by The Ukrainian Chamber of Commerce and Industry and published on the official website of the Ukrainian Seaports Administration. Thus, the Code of Customs of the Seaport of Odessa was issued on the basis of the order of the state enterprise "Administration of Seaports of Ukraine" dated 20.11.2015 № 233 and certified by The Ukrainian Chamber of Commerce and Industry 25.11.2015.

This Code establishes the rules for the provision of services, maintenance of ships and passengers, which have developed and have long been used in practice in the seaport of Odessa. The code of customs of the seaport of Odessa contains rules on: mode, planning of work in the seaport of Odessa, the order of work during the ice campaign, the order, conditions and sequence of acceptance of vessels for processing, the order of calculation of parking and standing time of the vessel in the seaport of Odessa, provision of services and their list, implementation of business operations, information interaction with the use of the information system of the port community, organizational support of economic activity, as well as other rules of business operations within the seaport of Odessa.

Considering the current regulatory framework for the operation of seaports in Ukraine, it should be noted that innovations in maritime infrastructure and port management of Ukraine were reflected in 2012 in the new Law on Seaports for Ukrainian legislation. This Law significantly renewed the institutional system 
of public administration of seaport activities, providing for a new governing body of the port industry - the Administration of Seaports of Ukraine. It is this state-owned enterprise that currently has a significant influence on the formation of the regime of seaports of Ukraine, ensuring their functioning, maintenance and use of port infrastructure of state ownership, other tasks assigned to it directly and through its branches formed in each sea port. It should be noted here that currently the system of public (state) administration of activities in the sea sweats of Ukraine continues to be updated and is at the "break" of the established and new practice. At the same time, unfortunately, these transformations are mostly caused not by objective circumstances and the desire for gradual improvement, but are caused by the violations and excess of powers (Serafimov, 2020).

Compulsory regulations on the port are adopted by the Administration of Seaports of Ukraine in coordination with the captain of the seaport and the central executive body, which ensures the implementation of state policy in the field of safety in maritime and river transport. This document contains information specific to each seaport on: 1) the boundaries of the surveillance zone, territory and waters of the seaport, including information on the depths in the seaport and on the approaches to the seaport, the technical capabilities of the seaport to accommodate ships; 2) areas of mandatory and optional pilotage, categories of vessels and requirements for captains of vessels exempt from mandatory pilotage, established by the central executive body that ensures the formation and implementation of state policy in the field of sea and river transport; 3 ) the procedure for navigation of vessels in the seaport, canals and fairways (unless they are established in the rules of navigation, approved by the central executive body that ensures the formation and implementation of state policy in the field of sea and river transport), including rules of access to seaport and departure from the seaport, the procedure for submitting 
information on the arrival and departure of vessels, the procedure for using means of communication in the seaport, the procedure for providing pilotage services; 4) rules of berthing of vessels, including coordinates of places for anchoring at the roadstead, rules of mooring and unmooring; 5) rules and established places for carrying out loading and unloading operations, the procedure for carrying out maintenance and repair of vessels in the seaport; 6) rules of safety and order in the seaport, the order of protection of ships and port facilities; 7) rules of environmental protection; 8) rules for dredging; 9) requirements of the sanitary and quarantine regime at the request of a subdivision of the state sanitaryepidemiological service in a seaport; 10) requirements of the fire regime in the seaport; 11) the procedure for disembarking persons of the ship's crew and their stay on the territory of the seaport and port city during the berth of the ship; 12) other information related to the safety of navigation in the seaport.

The procedure for passing border, customs and other types of control must comply with international standards and take into account Ukraine's obligations under international treaties of Ukraine, the binding nature of which has been approved by the Verkhovna Rada of Ukraine. If a checkpoint across the state border of Ukraine is opened in a seaport, the administration of seaports of Ukraine shall publish the established procedure for border and customs control in the mandatory resolutions on the port at the request of state border guards and customs authorities. Mandatory regulations on the port are binding on all legal entities and individuals who are in the seaport, after their mandatory state registration and publication in the Notices to Seafarers of Ukraine. When adopting mandatory resolutions on the port or making changes to them, it is not allowed to narrow the content and scope of the existing rights of the subjects of port activity, provided by the Constitution and laws of Ukraine.

Compulsory regulations on the seaport of Odessa, approved by the order of the state enterprise "Administration of Seaports of Ukraine" 
dated 22.12.2015 № 266, determine that they are mandatory for implementation in the seaport of Odessa by all legal entities and individuals. The requirements of the Mandatory Regulations apply to ships, ships and other vessels of all flags located in the waters of the port of Odessa, regardless of their departmental affiliation and forms of ownership (paragraph 1.3). Identical norms contain mandatory regulations for all seaports of Ukraine (Southern, Mykolaiv, Kherson, etc.).

\section{Conclusions}

Thus, if the program documents of long-term strategic planning in the maritime sphere of Ukraine do not contain generalized norms on the regimes of seaports (it is noted the need to improve their individual components), then in other legislation they are present and regulated in detail. At the same time, such regulations have a clearly specified nature, comprehensively outline all components of seaport regimes, but only from the standpoint of domestic law, without taking into account the rules of international (bilateral) agreements on merchant shipping. There is no mention of the establishment of such agreements by certain regime rules in the seaports of Ukraine. At the same time, these agreements determine one of the largest components of the integrated regime of seaports - the regime of ships under foreign flags and the regime of their crews. And, in our opinion, the introduction of relevant changes in the current legislation, namely the indication in it of the determination of such a regime by the rules of bilateral agreements on merchant shipping could help update the current legislation and enshrine additional guarantees for foreign shipowners. These norms can also be enshrined in the future law of Ukraine on inland waters, the territorial sea and the continental shelf, the drafts of which have long been periodically considered by the Verkhovna Rada of Ukraine, but have not yet been implemented. 


\section{REFERENCES}

Averochkina, T.V. (2018). Yurysdyktsiia Ukrainy v pryberezhnykh vodakh: administratyvno-pravovyi vymir. [Jurisdiction of Ukraine in coastal waters: administrative and legal dimension] Odessa: Vydavnychyi dim "Helvetyka". [in Ukrainian].

Brazovskaya Ya.E., Zhelonkin S.S. (2019). Historical-legal analysis of unification of document on arrival of merchant ships into foreign ports. Actual Problems of Economics and Law, 13, 4, 1637-1645. http://dx.doi.org/10.21202/1993047X.13.2019.4.1637-1645 [in Russian].

Convention and Statute on the International Regime of Maritime Ports, 1923 (League of Nations). League of Nations Treaty Series. Geneva, 1926-1927, 1379 .

Convention on Facilitation of International Maritime Traffic, 1965 (International Maritime Organization). Treaties.un.org. Retrieved April 24, 2020, from: https://treaties.un.org/doc/Publication/UNTS/Volume\%20591/volume-591-I8564-English.pdf

De Sousa, J.F., Fernandes, A. (2009). The Port of Funchal: Conserving a Balance between Maritime-Port Functions and Port/City Integration. Researchgate. Retrieved April 25, 2020, from: https://www.researchgate.net/publication/303541815_The_Port_of_Funchal_Conserving_a_Balance_between Maritime-Port_Functions_and_PortCity_Integration

Dimitriou D.J., Mourmouris, J.C., Sartzetaki, M.F. (2017). Maritime ports economic effect on regional development: estimations for the major maritime ports in Greece. International Journal of Decision Support Systems, 2, 4, 210-220. https://doi.org/10.1504/IJDSS.2017.092250

Kivalov, S.V. (2018). Transformatsiia Morskoi doktryny Ukrainy: kontseptualni zasady [Transformation of the Maritime doctrine of Ukraine: conceptual bases]. Lex Portus, no. 5, 7-26. https://doi.org/10.26886/2524-101X.5.2018.1 [in Ukrainian].

Kormych, B., Averochkina, T. \& Gaverskyi, V. (2020). The public administration of territorial seas: Ukrainian case. Int Environ Agreements. https://doi.org/10.1007/s10784-020-09473-9

Kuznetsov S.O., Averochkina, T.V. (2011). Morske parvo [Maritime law]. Odesa: Feniks. [in Ukrainian].

Mailjan, S.S. (2002). Administrativno-pravovye rezhimy v teorii administrativnogo prava i praktike gosudarstvennogo upravlenija pravoohranitel'noj deja- 
tel'nost'ju [Administrative and legal regimes in the theory of administrative law and the practice of public administration of law enforcement]. Moscow: JuNITI-DANA, Zakon i pravo. [in Russian].

Nakaz pro zatverdzhennia Oboviazkovykh postanov po morskomu portu Odesa, 2015 (Administratsiia morskykh portiv Ukrainy) [Order on approval of compulsory regulations on the Seaport of Odessa, 2015 (Ukrainian Sea Ports Authority)]. Veb-sait Administratsii Odeskoho morskoho portu. [Website of the Odessa Sea Port Authority]. Retrieved April 2, 2020, from: http://www.port.odessa.ua/images/compulsory-regulations.pdf [in Ukrainian].

Nakaz pro zatverdzhennia Oboviazkovykh postanov po morskomu portu Yuzhnyi, 2016 (Administratsiia morskykh portiv Ukrainy) [Order on approval of compulsory regulations on the seaport Yuzhny, 2016 (Ukrainian Sea Ports Authority)]. Veb-sait Administratsii morskykh portiv Ukrainy. [Website of the Ukrainian Sea Ports Authority]. Retrieved April 2, 2020, from: http://www.uspa.gov.ua/images/25.04.2016.pdf [in Ukrainian].

Nakaz pro zatverdzhennia Oboviazkovykh postanov po morskomu portu Mykolaiv, 2016 (Administratsiia morskykh portiv Ukrainy) [Order on approval of compulsory regulations on the Seaport of Mykolaiv, 2016 (Ukrainian Sea Ports Authority)]. Veb-sait Administratsii morskykh portiv Ukrainy. [Website of the Ukrainian Sea Ports Authority]. Retrieved April 2, 2020, from: http:// www.uspa.gov.ua/images/registers_seaport_ukraine/Niko.pdf [in Ukrainian].

Nakaz pro zatverdzhennia Oboviazkovykh postanov po morskomu portu Kherson, 2016 (Administratsiia morskykh portiv Ukrainy) [Order on approval of compulsory regulations on the Seaport of Kherson, 2016 (Ukrainian Sea Ports Authority)]. Veb-sait Administratsii morskykh portiv Ukrainy. [Website of the Ukrainian Sea Ports Authority]. Retrieved April 2, 2020, from: http://www.uspa.gov.ua/images/Kherson.pdf [in Ukrainian].

Nakaz pro zatverdzhennia Poriadku oformlennia prykhodu suden u morskyi port, nadannia dozvolu na vykhid suden u more ta oformlennia vykhodu suden iz morskoho portu, 2013 (Ministerstvo infrastruktury Ukrainy) [Order on approval of the Procedure for registration of arrival of vessels in the seaport, granting permission for exit of vessels to the sea and registration of exit of vessels from the seaport, 2013 (Ministry of Infrastructure of Ukraine)]. Ofitsiinyi visnyk Ukrainy. [Official Bulletin of Ukraine], 76, 2857. [in Ukrainian].

Nakaz pro zatverdzhennia Poriadku oformlennia prykhodu z reisu $i$ vykhodu $v$ reis suden flotu rybnoi promyslovosti kapitanamy morskykh rybnykh portiv Ukrainy, 2006 (Ministerstvo ahrarnoi polityky Ukrainy) [Order on approval of the Procedure for registration of arrival from flight and departure of vessels of 
the fishing industry by captains of sea fishing ports of Ukraine, 2006 (Ministry of Agrarian Policy of Ukraine)]. Ofitsiinyi visnyk Ukrainy. [Official Bulletin of Ukraine], 8, 467. [in Ukrainian].

Postanova pro pryiniattia Ukrainoiu Konventsii pro polehshennia mizhnarodnoho morskoho sudnoplavstva 1965 roku z popravkamy, 1993 (Kabinet Ministriv Ukrainy) [Resolution on the adoption by Ukraine of the Convention on Facilitation of International Maritime Ttaffic of 1965, as amended, 1993 (Cabinet of Ministers of Ukraine)]. Ofitsiynyy sayt Verkhovnoyi Rady Ukrayiny. [The official website of the Verkhovna Rada of Ukraine]. Retrieved April 7, 2020, from: https://zakon.rada.gov.ua/laws/show/775-93-п [in Ukrainian].

Rozporiadzhennia pro skhvalennia Natsionalnoi transportnoi stratehii Ukrainy na period do $2030 \mathrm{roku}, 2018$ (Kabinet Ministriv Ukrainy) [The resolution on Approval of the National Transport Strategy of Ukraine for the period up to 2030, 2018 (Cabinet of Ministers of Ukraine)]. Ofitsiinyi visnyk Ukrainy. [Official Bulletin of Ukraine], 52, 533, 1848. [in Ukrainian].

Postanova pro zatverdzhennia Morskoi doktryny Ukrainy na period do 2035 roku, 2009 (Kabinet Ministriv Ukrainy) [The Resolution on approval of the Maritime Doctrine of Ukraine for the period up to 2035, 2009 (The Cabinet of Ministers of Ukraine)]. Ofitsiinyi visnyk Ukrainy. [The Official Bulletin of Ukraine], 94, 3216. [in Ukrainian].

Postanova pro vnesennia zmin do Morskoi doktryny Ukrainy na period do 2035 roku, 2018 (Kabinet Ministriv Ukrainy) [The Resolution on Amendments to the Maritime Doctrine of Ukraine for the Period up to 2035, 2018 (The Cabinet of Ministers of Ukraine)]. Ofitsiinyi visnyk Ukrainy. [The Official Bulletin of Ukraine], 2019, 2, 85, 53. [in Ukrainian].

Rozporiadzhennia pro zatverdzhennia Stratehii rozvytku morskykh portiv Ukrainy na period do 2038 roku (2013) (Kabinet Ministriv Ukrainy) [An Order on Approval of the Strategy for the Development of Seaports of Ukraine for the Period until 2038 (2013) (Cabinet of Ministers of Ukraine)]. Ofitsiinyi visnyk Ukrainy. [Official Bulletin of Ukraine], 61, 45, 2194. [in Ukrainian].

Serafimov, V. (2020). Supervision (control) in the sphere of marine environment protection in Ukraine: new institutional transformations. Lex Portus, 1, 23-36. https://doi.org/10.26886/2524-101X.1.2020.2

Tihomirov, Ju.A. (2001). Administrativnoe pravo i process. Polnyj kurs. [Administrative law and process. Full course]. Moscow: izdatel'stvo Tihomirov M. Ju. [in Russian].

Tychkova, O.Iu. (2009). Lokalni korporatyvni normy u tsyvilno-pravovomu rehuliuvanni [Local corporative acts in civil adjustment]. Kharkiv. [in Ukrainian]. 
Zakon pro morski porty Ukrainy, 2012 (Verkhovna Rada Ukrainy). [Law on Ukrainian Seaports, 2012 (Verkhovna Rada of Ukraine)]. Ofitsiinyi visnyk Ukrainy. [Official Bulletin of Ukraine], 45, 1729. [in Ukrainian].

Zaucha, J., Matczak, M. (2018). Role of maritime ports and shipping in the creation of the economic value of the sea areas. SHS Web Conf., 58, 01033. https://doi.org/10.1051/shsconf/20185801033

Zvid zvychaiv morskoho portu Odesa, 2015 (Administratsiia morskykh portiv Ukrainy) [Code of Practice of the Odessa seaport (Ukrainian Sea Ports Authority)]. Veb-sait Administratsii morskykh portiv Ukrainy. [Website of the Ukrainian Sea Ports Authority]. Retrieved April 2, 2020, from: http://www.uspa.gov.ua/images/other_files/Svody_obychaev/svod_odessa.pdf [in Ukrainian].

\section{Андрущенко С. Режим морських портів в Украӥні: складний шлях} оновлення правового регулювання. - Стаття.

У статті окреслено переваги та недоліки діючого законодавства України у сфері встановлення правового режиму морських портів. Проаналізовано документи довгострокового стратегічного планування у морській сфері, міжнародні угоди та галузеве (портове) законодавство. Визначено, що ані програмні документи морської сфери України, ані інше національне законодавство портової сфери не містять узагальнених норм про режими морських портів, але окреслюють їх складники. У перших - зазначається про необхідність та шляхи їх поліпшення, а у другому - ці складники детально регламентовані та чітко конкретизовані, комплексно характеризують встановлені режими морських портів, проте лише з позицій внутрішнього законодавства, не враховуючи норм міжнародних (двосторонніх) угод про торговельне мореплавство. При цьому, саме цими угодами визначається один з найбільших елементів комплексного режиму морських портів - режим суден під іноземними прапорами та режим їх екіпажів. Автор пропонує внесення змін до діючого законодавства України у сфері портової діяльності та зазначення у ньому про детермінованість режимів морських портів України не лише внутрішнім законодавством, але й нормами двосторонніх угод про торговельне мореплавство. Також відзначається, що такі норми можуть отримати своє закріплення у майбутньому законі України про внутрішні морські води, територіальне море та континентальний шельф.

Ключові слова: порт, морський порт, режим морського порту, розвиток портового законодавства, публічне адміністрування портової діяльності. 
Андрущенко С. Режим морских портов в Украине: сложный путь обновления правового регулирования. - Статья.

В статье рассмотрены преимущества и недостатки действующего законодательства Украины в сфере определения правового режима морских портов. Проанализированы документы долгосрочного стратегического планирования в морской сфере, международные соглашения и отраслевое (портовое) законодательство. Определено, что ни программные документы морской сферы Украины, ни другое национальное отраслевое законодательство не содержат обобщенных норм о режимах морских портов, но определяют их составляющие. В первых - отмечается о необходимости и путях их улучшения, а во втором - эти составляющие детально регламентированы и четко конкретизированы, комплексно характеризуют установленные режимы морских портов, но только с позиций внутреннего законодательства, не учитывая норм международных (двусторонних) соглашений о торговом мореплавании. При этом, именно этими соглашениями определяется один из важнейших элементов комплексного режима морских портов - режим судов под иностранными флагами и режим их экипажей. Автор предлагает внести изменения в действующее законодательство Украины в сфере портовой деятельности с указанием в нем о детерминированности режимов морских портов Украины не только внутренним законодательством, но и нормами двусторонних соглашений о торговом мореплавании. Также отмечается, что такие нормы могут получить свое закрепление в будущем законе Украины о внутренних морских водах, территориальном море и континентальном шельфе.

Ключевые слова: порт, морской порт, режим морского порта, развитие портового законодательства, публичное администрирование портовой деятельности. 